\title{
Návrh modelu připravenosti pro hodnocení interních logistických procesů v kontextu Průmyslu 4.0
}

\author{
Michal Zoubek ${ }^{1}$, Michal Šimon ${ }^{1}$ \\ 1 Západočeská univerzita v Plzni, Fakulta strojní, Katedra průmyslového inženýrství a \\ managementu \\ Univerzitní 2732/8, 30614 Plzeň, Česká republika \\ zoubekm@kpv.zcu.cz \\ simon@kpv.zcu.cz
}

\begin{abstract}
Anotace: Koncept Průmysl 4.0 dostal svůj název podle čtvrté průmyslové revoluce, která právě probíhá. Vznikl před pár lety $\vee$ Německu a jeho posláním je řešit situaci, kterou způsobila čtvrtá průmyslová revoluce, kterou zcela evidentně vyvolal internet a digitalizace. Zatímco předchozí etapa digitalizace přinesla do průmyslu počítače a roboty, čtvrtá průmyslová revoluce je mezi sebou propojila a naučila je komunikovat. Podniky na tento vývoj musí být prípraveny a jejich prípravenost a zralost hodnotí modely pripravenosti. Nalezené modely jsou analyzovány a porovnávány a jsou hlavním předmětem teoretické části článku. Právě nový model připravenosti je hlavní náplní tohoto článku a záměrem je představit nástroj pro komplexní hodnocení interní logistiky, která obsahuje klíčové procesy jako je interní manipulace, skladování nebo balení. Interní logistika má tedy v rámci tohoto konceptu velký potenciál a představuje pro logistiku přiležitosti pro růst a rozvoj. Nicméně důležité je znát současnou úroveň na základě diagnostiky a $\mathrm{k}$ tomu slouží právě navržený model.
\end{abstract}

\section{1 Úvod - koncept Průmyslu 4.0}

Průmysl 4.0 má široký rozsah a netýká se jen implementace nových technologií do průmyslových podniků a postupné automatizace nahrazující lidskou sílu. Vzhledem $\mathrm{k}$ jeho rozsahu existují definice a pohledy od akademiků, společností, poradenských společností nebo praktických sdružení. Vyjadřující se subjekty se ale shodují na tom, že podstatou Průmyslu 4.0 je digitalizace, rozšiřování vysokorychlostního internetu, rozvoj chytrých technologií, komunikace a raada dalších témat. Podniky, které si chtějí udržet svou konkurenceschopnost a postavení na trhu musí podstoupit první kroky směrem k digitalizaci již dnes. Digitalizace slibuje nižší náklady, vyšší kvalitu výroby, flexibilitu a efektivitu. Investice do digitalizace mají zásadní význam pro růst všech průmyslových firem bez ohledu na jejich velikost nebo odvětví. Průmysl a celá ekonomika prochází zásadními změnami způsobenými zaváděním informačních technologií, kybernetickofyzických systémů umělé inteligence do výroby, služeb a všech odvětví hospodářství. Dopad těchto změn je tak zásadní, že se o nich mluví jako o 4. průmyslové revoluci. Hlavní historické milníky jsou takové, hlavní definice 
Průmysl 4.0 vychází z dokumentu prezentovaného na veletrhu $v$ Hannoveru $v$ roce 2013. Základní vize čtvrté průmyslové revoluce vznikla v roce 2011.

Vývoj k Průmyslu 4.0 na základě digitalizace a automatizace představuje pro oblast logistiku obrovské výzvy a také příležitosti pro další růst a rozvoj. Oblast logistiky má tedy $v$ rámci tohoto konceptu velký potenciál. Nicméně je důležité a nutné se více konkretizovat, protože oblast logistiky je velmi široká. Zaměřujeme se $v$ dalších částech tohoto článku na oblast interní logistiky. Připravenosti podniků na Průmysl 4.0 je hodnocena dle modelů připravenosti, které podnik rozdělují do několika oblastí a hodnotí prípravenosti príslušných procesů do několika úrovní. Nejvyšší úroveň koresponduje s Průmyslem 4.0

\subsection{Definice a hlavní principy Průmyslu 4.0}

Jak bylo zmíněno, mluvíme o čtvrté průmyslové revoluci, která již probíhá. Má svá specifika a je již jasné, že má významné dopady nejen na oblast průmyslu, ale také na chování lidí a podniků. Nástup tohoto konceptu změní naši společnost. Podniky budou muset změnit procesy, se kterými doposud pracovaly a prizpůsobit se nové době. [1]

Nejvíce skloňované pojmy v rámci konceptu Průmyslu 4.0 - automatizace, digitalizace a robotizace zažívají největší rozmach, a proto mění fungování průmyslu, výroby, ale i myšlení a chování společnosti. Změny způsobené čtvrtou průmyslovou revolucí se dotknou i oblasti vzdělání a pracovního trhu. [2]

Stručný vývoj revolucí je takový, že první tři průmyslové revoluce vznikly $v$ důsledku mechanizace, využití elektřiny a využití výpočetní techniky. Zavedení internetu věcí a služeb do výrobního prostředí nyní představuje čtvrtou průmyslovou revoluci. $V$ budoucnu budou průmyslové podniky zavádět globální sítě, do kterých budou začleněny stroje a výrobní zařizení, skladové systémy a výrobní zařizení ve formě kybernetických fyzických systémů (CPS - cyberphysical systems). Ve výrobním prostředí tyto kybernetické fyzikální systémy zahrnují inteligentní stroje, skladovací systémy a výrobní zařízení, která jsou schopna samostatně si vyměňovat informace, spouštět akce a vzájemně se nezávisle ovládat - důležitá je tedy jejich autonomnost. [3]

Průmysl 4.0 a jeho implementace naznačují změny $v$ obchodních paradigmatech a výrobních modelech, které se projeví na všech úrovních výrobních procesů a dodavatelských řetězců, včetně všech pracovníků ve výrobním procesu, manažerů, konstruktérů kybernetických systémů a koncových uživatelé. Implementační strategie konceptu Průmyslu 4.0 do podnikových sektorů znamená zavedení samostatné automatizace, konfigurace, diagnostiky a řešení problémů, dále nových znalostí a inteligentního rozhodování. [4] 
Pokud definujeme Průmysl 4.0 na základě piliríu digitalizace, je založen na těchto třech hlavních piliřích [5]:

1) Digitalizace a integrace horizontálních a vertikálních hodnotových řetězců

- $\quad$ probíhá v celé organizaci

- vertikální procesy spojené s horizontálními procesy

- $\quad$ veškerá data o operacích a plánování procesů Ize provádět $v$ reálném čase

- $\quad$ provádět Ize pomocí podpory rozšířené reality

2) Digitalizace nabízených produktů a služeb

- používání inteligentních produktů

- $\quad$ přidání inteligentních senzorů nebo komunikačních zařízení, které Ize použít s analytickými datovými nástroji

- $\quad$ vytváření nových digitalizovaných produktů

- $\quad$ integrace nových metod pro sběr a analýzu dat

- $\quad$ virtuální návrhy nejen produktů, ale také výrobních prostředků a procesů

3) Digitalizace podniků a prístup k zákazníkům

- $\quad$ úzce souvisí s internetem věcí a internetem služeb

- systémy CRM integrují sociální sítě a analýzu dat,

- $\quad$ zákazníci poskytují recenze.

Principy inteligentní výroby a logistiky jsou také základní hybnou sílou pro maximalizaci přidané hodnoty jednotlivých procesů např́č podnikem, která je dána součinností klíčových principů na základě interoperability, decentralizace, inteligence, rekonfigurability a dalších. [6] Jednotlivé atributy jsou s charakteristikou uvedeny v tabulce 1.

Tabulka 1 - Principy inteligentní výroby [6]

\begin{tabular}{|l|l|}
\hline Interoperabilita & $\begin{array}{l}\text { V podnikovém prostředí to znamená propojení strojů, } \\
\text { lidí, materiálů produktů, informačních a } \\
\text { komunikačních technologií a systému } \\
\text { (interkonektivita systému) }\end{array}$ \\
\hline Virtualizace & $\begin{array}{l}\text { Znamená vytvorení virtuální kopie chytré továrny } \\
\text { propojením údajů z fyzických senzorů } \mathrm{S} \text { virtuálními } \\
\text { údaji ze simulačních modelů továrny }\end{array}$ \\
\hline
\end{tabular}




\begin{tabular}{|l|l|}
\hline Decentralizace & $\begin{array}{l}\text { Schopnost kyberneticko-fyzikálních systémů } \\
\text { rozhodovat samy za sebe a produkovat. }\end{array}$ \\
\hline Real-time & $\begin{array}{l}\text { Schopnost shromažd'ovat a analyzovat údaje; } \\
\text { získané poznatky okamžitě poskytovat (řádově v } \\
\text { milisekundách). }\end{array}$ \\
\hline $\begin{array}{l}\text { Orientace na } \\
\text { služby }\end{array}$ & $\begin{array}{l}\text { Jednotky softwaru rozdělené na diskrétní, autonomní } \\
\text { a sítově přístupné jednotky, z nichž každá je } \\
\text { navržena k řešení individuálního zájmu. }\end{array}$ \\
\hline $\begin{array}{l}\text { Modularita a } \\
\text { rekonfigurabilita }\end{array}$ & $\begin{array}{l}\text { Pružná adaptace chytrých továren na měnící se } \\
\text { požadavky tím, že se nahradí nebo rozšǐrí jednotlivé } \\
\text { moduly }\end{array}$ \\
\hline
\end{tabular}

Další pohled na koncept Průmysl 4.0 je založen na hluboké průmyslové integraci prostřednictvím informačních technologií a s ní spojením zpracování dat $v$ reálném čase, sdílení informací a kontinuální komunikaci. Technologické atributy konceptu zmiňuje podobně většina autorů, napríiklad dle autora Maříka [7] se jedná o velká data, kyberneticko-fyzické systémy (CPS), cloudové úložiště, implementace autonomních robotů, internet věcí, využití rozšírené reality, aditivní výroba, senzorika. Popis detailní jednotlivých technologií je nad rámec článku.

Hlavní charakteristiky inteligentních průmyslových podniků odpovídajících konceptu Průmyslu 4.0 Ize shrnout následovně:

- výrobní procesy jsou optimalizované $v$ rámci celého hodnotového řetězce díky vertikálně i horizontálně integrovaným IT systémům,

- $\quad$ izolované výrobní jednotky jsou nahrazeny plně automatizovanými a vzájemně propojenými výrobními linkami,

- $\quad$ fyzické prototypy jsou nahrazeny virtuálními návrhy výrobků, výrobních prostředků a výrobních procesů, jejich uvedení do provozu probíhá v rámci jednoho integrovaného procesu zapojujícího jak výrobce samotného, tak i jeho dodavatele,

- $\quad$ flexibilní výrobní procesy umožňují efektivní výrobu i malých výrobních dávek přizpůsobených individuálním požadavků jednotlivých zákazníků,

- $\quad$ vzájemně komunikující roboty, výrobním zařízením a výrobky činí do jisté míry autonomní rozhodnutí v reálném čase a tím zvyšují flexibilitu a efektivitu výrobního procesu,

- výrobní zařízení se samo optimalizuje a konfiguruje v závislosti na parametrech zpracovávaného produktu,

- $\quad$ automatizované logistické zázemí využívající autonomních vozíků a robotů se automaticky přizpůsobuje potřebám výroby. [7], [8] 


\subsection{Logistika 4.0}

Zatímco předchozí etapa digitalizace přinesla do průmyslu počítače a roboty, 4. průmyslová revoluce je mezi sebou propojila a naučila je komunikovat. $U$ konceptu chytrých továren je klíčová ona schopnost propojit mezi sebou všechny operující stroje. Logistika 4.0 je klíčovým prvkem digitalizace, i když zatím není tak populárním tématem, jako Průmysl 4.0. Tento koncept má samožrejmě velký rozsah a značný vliv na oblasti interní logistiky.

Logistika 4.0 je „kolektivní terminologií pro technologie a koncepty hodnotového řetězce organizace." Nejdủležitější je implementovat všechny logistické procesy v organizaci při zachování zásad konceptu Průmyslu 4.0. Vývoj logistiky byl založen hlavně na konkrétních změnách (inovacích) ve čtyřech etapách:

- existence mechanizace dopravy na konci 19. a na počátku 20. (Logistika 1.0.),

- automatizace manipulačního systému zboží v 60. letech (Logistika 2.0.),

- $\quad$ inovace $v$ systémech pro správu logistiky v 80. letech (Logistika 3.0.)

- $\quad$ existence internetu věcí a služeb (IoT, loS) a velkých dat, která mají důsledky pro logistiku (Logistika 4.0). [9]

Všechny aplikace, technologie a principy Průmyslu 4.0 v logistické oblasti spadají pod jmenovatel Logistika 4.0. Dále popisuje efektivnost procesu jako důležitý ukazatel logistiky, který Ize získat realizací zásad Průmyslu 4.0 (interoperabilita, transparentnost informací, virtualizace, modularita, servisní orientace, technická pomoc) $v$ klíčových logistických oblastech jako skladování, doprava, balení, distribuce, nakládka/vykládka a informační služby. [10]

Většina autorů popisujících logistiku $v$ rámci konceptu Průmyslu 4.0 identifikuje a zmiňuje podobné technologie a aplikace, které jsou založeny na principech tohoto konceptu a implementovány $v$ oblasti interní logistiky. Přední technologie Logistiky 4.0 jsou uvedeny podle jejich zdrojů v tabulce 2.

Tabulka 2 - Hlavní technologie Logistiky 4.0

\begin{tabular}{|l|l|}
\hline Zdroj & Technologie Logistiky 4.0 \\
\hline $\begin{array}{l}\text { Wang (2016) } \\
{[9]}\end{array}$ & $\begin{array}{l}\text { Big Data, „smart“ senzory, RFID, IoT, IoS, } \\
\text { „Smart“ robots, autonomní AGV, GPS }\end{array}$ \\
\hline $\begin{array}{l}\text { Galindo (2016) } \\
{[11]}\end{array}$ & RFID, CPS, loT, IoS, Big Data, RTLS, \\
\hline $\begin{array}{l}\text { Glistau and } \\
\text { Machado }\end{array}$ & $\begin{array}{l}\text { RFID, WLAN, EDI, GPRS, Big Data, Data } \\
\text { Mining, „smartphones“, EDI, 5G network, }\end{array}$ \\
\hline
\end{tabular}




\begin{tabular}{|l|l|}
\hline (2018) [12] & tablety, cloudy \\
\hline $\begin{array}{l}\text { Zou and Zhong } \\
\text { (2018) [13] }\end{array}$ & $\begin{array}{l}\text { Autonomní AGV, drony, kolaborativní roboti, } \\
\text { RFID }\end{array}$ \\
\hline
\end{tabular}

\section{Připravenost podniků na koncept Průmyslu 4.0}

Zatímco předchozí průmyslová etapa digitalizace přinesla do průmyslu počítače a roboty, 4. průmyslová revoluce je mezi sebou propojila a naučila je komunikovat. U konceptu chytrých továren je klíčová ona schopnost propojit mezi sebou všechny operující stroje. Tempo přijetí konceptu Průmyslu 4.0 je však $v$ různých průmyslových odvětvích a společnostech nerovnoměrné $a$ rozdílné. Společnosti se potýkají globálně i lokálně s konceptem Průmyslu 4.0 a hodnotou, kterou by mohl přinést. Pro tyto společnosti jsou důležité odpovědi na takové otázky jako - co je to Průmysl 4.0 a jak může efektivně prospět společnosti? Jak začít implementovat moderní technologie a jaká je připravenosti podniku? Kde jsou príležitosti pro implementaci?

$\checkmark$ této části článku je popsána problematika modelů pripravenosti na koncept Průmysl 4.0 , které se běžně používají pro měření zralosti organizace nebo procesu týkajícího se konkrétního cílového stavu. Charakteristické pro modely je jejich využití, protože na základě jejich využití je možné identifikovat současný stav a připravenost na koncept Průmyslu 4.0 komplexně v celém podniku nebo $v$ různých oblastech podniku. Případně se modely snaží hledat potenciální místa pro zlepšení stavu připravenosti do budoucna. Modely připravenosti se vyskytují v mnoha modifikacích, rozsazích a ty komplexní modely by měly vybavit společnosti praktickými znalostmi o aspektech:

- co je to Průmysl 4.0 a jaké jsou hmatatelné výhody, které by mohl přinést,

- jaká je úroveň prípravenosti společnosti a dílčích oblastí a zařízení,

- jak se společnost může postupně a cílené zlepšovat a zvyšovat úroveň.

\subsection{Obecný přehled modelů připravenosti}

Klíčovým konceptem, ze kterého vychází většina typů modelů připravenosti, je Capability Maturity Model (CMM), později vyvinutý model Capability Maturity Model Integration (CMMI).

Obsahuje základní prvky efektivních procesů pro jednu nebo více disciplín a popisují cestu evolučního zlepšování od nezralých procesů k disciplinovaným a zralým procesům se zlepšenou kvalitou a účinností. [14] Stručně je to model, který má za cíl pomoci $v$ organizaci plánovat, definovat, implementovat, rozvíjet, hodnotit a zlepšovat procesy. Nejedná se o metodiku, ale model určující cíle, kterých by měl podnik dosáhnout a to bez přesně předepsaných postupů. [15] Model CMMI pracuje s pěti úrovněmi zralosti, od 
první nejnižší počáteční úrovně, přes řízenou, definovanou, kvantitativně řízenou až po nejvyšší pátou optimalizující úroveň. [16] Podobným další modelem je SPICE (Software Process Improvement and Capability Determination). $\mathrm{Na}$ základě SPICE byly vytvořeny další modely pro posuzování procesů, zejména Automotive SPICE pro automobilový průmysl. Tento model pracuje se šesti úrovněmi připravenosti, od úrovně 0 a nekompletního procesu, až po úroveň 5, kde proces je optimalizovaný. [17]

Jednotlivé modely připravenosti na Průmyslu 4.0 mají založené základy na stejných, či velmi podobných principech jako modely CMMI, proto bylo důležité tyto modely zmínit. Definované jsou vždy analyzované oblasti (dimenze). U některých modelů jsou dimenze dále rozšířená na dílči dimenze. Vedle dimenzí je dále důležitý zpưsob hodnocení. Podobnost ve způsobu hodnocení je dána jednotlivými stupni zralosti $v$ daných oblastech (dimenzích). Stupňů připravenosti je většinou čtyřii až šest. Jsou seřazeny logicky od nejnižšího stupně až po stupeň nejvyšší. Stupně mají svoje názvy a vlastní charakteristiku požadavků a vlastností pro splnění daného stupně v rámci dané oblasti (dimenze). Připravenost podniku je také u některých modelů vyjádřena kvantitativním způsobem formou indexu připravenosti.

\subsection{Hlavní aspekty modelů připravenosti}

Základním rozdělením modelů pro hodnocení prípravenosti je dle úrovně rozsahu. Modely mohou být rozdělené:

1) makro úrovni, kde je prováděno hodnocení ve vztahu $k$ zemím a ukazují předpoklady pro rozvoj průmyslu a digitalizaci průmyslu sledovaných jednotlivých zemí, prioritou je zlepšit konkurenceschopnost dané země zvýšením její inovační schopnosti a digitalizace.

2) mikro úrovni, které hodnotí připravenost samotného subjektu podniku. [18]

Na mikro úrovni není nutné porovnávat velké množství společností a desítky ukazatelů. Hodnotí se samotný podnik, prípadně jeho dílčí oblasti. [19]

$\checkmark$ rámci této rešerše je zaměřeno na mikro modely, pro které existuje mnoho modifikací a metodik. Cílem je analyzovat jednotlivé modely a jejich hlavní atributy. Charakterizované modely prripravenosti jsou různé kvality a rozsahu zpracování, některé jsou velmi komplexní, některé stručnější podoby. U jednotlivých modelů byla provedena analýza $s$ uvedením hlavních charakteristik a atributů:

Původ zdroje - Modely jsou zejména ze zahraničních univerzit, různých strojírenských sdružení, poradenských společností, často jsou kombinovány akademickou sférou a průmyslovým sdružením.

Analyzované dimenze a oblasti - Vypsány jsou všechny analyzované dimenze př́slušeného zkoumaného modelu. Dimenze jsou v počtu od minima 
3 dimenzí až 9 dimenzí. U některých modelů se dimenze ještě rozdělují na dílčí dimenze, tj. subdimenze.

Způsob hodnocení připravenosti - Pro výsledné hodnocení jsou použity modely s několika úrovněmi (stupni), často od 4 do 6 úrovní, a tyto úrovně jsou charakterizovány.

Záměr modelu - Model připravenosti může být využíván ke stanovení a hodnocení současného stavu připravenosti a zařazení do příslušného stupně, tj. účel deskriptivní - popisný. Nebo může být model připravenosti charakteru comparative - srovnávacího. Třetí vlastností může být preskriptivní model, tj. předpisující,

Hodnocení interní logistiky - $U$ modelů připravenosti byla hledaná hlavní oblast, kterou je interní logistika. Modely jsou rozděleny do třech skupin $A, B$, $C$. Ve skupině $A$ jsou modely, které jsou koncipované přímo na hodnocení interní logistiky, modely zařazené do skupiny B obsahují interní logistiku částečně $v$ některé $z$ oblastí. Modely ve skupině $C$ se logistice nevěnují $a$ nehodnotí interní logistické procesy.

Kategorie modelu - Hlavními kategoriemi provedení modelů jsou „roadmaps“, zralostní modely, modely připravenosti nebo tzv. „frameworks" pro hodnocení.

Jednotlivé modely byly detailně analyzovány a jejich souhrn s hlavními charakteristikami vidíte $v$ tabulce 3 .

Tabulka 3 - Modely pripravenosti a jejich hlavní atributy

\begin{tabular}{|l|l|l|l|l|l|l|}
\hline $\begin{array}{l}\text { Model } \\
\text { připravenosti }\end{array}$ & Zdroj & $\begin{array}{l}\text { Původ } \\
\text { zdroje }\end{array}$ & $\begin{array}{l}\text { Počet } \\
\text { dimenzí }\end{array}$ & $\begin{array}{l}\text { Skup. } \\
\text { modelů }\end{array}$ & $\begin{array}{l}\text { Způsob } \\
\text { hodnocení }\end{array}$ & $\begin{array}{l}\text { Záměr } \\
\text { modelu }\end{array}$ \\
\hline $\begin{array}{l}\text { Impuls - } \\
\text { Industrie 4.0 } \\
\text { Readiness [20] }\end{array}$ & $\begin{array}{l}\text { Lichtbl } \\
\text { au et } \\
\text { al. } \\
\text { (2015) }\end{array}$ & $\begin{array}{l}\text { Akad. } \\
\text { Prakt. } \\
\text { sdr. }\end{array}$ & 6 & B & $\begin{array}{l}5 \text { úrovní od 1 } \\
\text { (Outsider) po } \\
5 \text { (Top } \\
\text { performer) }\end{array}$ & $\begin{array}{l}\text { Srov. } \\
\text { Popisný } \\
\text { Předpis. }\end{array}$ \\
\hline $\begin{array}{l}\text { Maturity Model } \\
\text { for Assessing } \\
{[21]}\end{array}$ & $\begin{array}{l}\text { Caroli } \\
\text { s et al. } \\
\text { (2017) }\end{array}$ & $\begin{array}{l}\text { Akad. } \\
\text { Prakt. } \\
\text { sdr. }\end{array}$ & 5 & B & $\begin{array}{l}5 \text { úrovní od 1 } \\
\text { (Počáteční) } \\
\text { po 5 (Digitální } \\
\text { orientovaný) }\end{array}$ & Popisný \\
\hline $\begin{array}{l}\text { An Industry 4 } \\
\text { Readiness } \\
\text { Assessment } \\
\text { Tool [22] }\end{array}$ & $\begin{array}{l}\text { Agca } \\
\text { et al. } \\
\text { (2018) }\end{array}$ & $\begin{array}{l}\text { Akad. } \\
\text { Porad. } \\
\text { spol. }\end{array}$ & 6 & B & $\begin{array}{l}6 \text { úrovní od 1 } \\
\text { (Začátečník) } \\
\text { po 4 (Expert) }\end{array}$ & $\begin{array}{l}\text { Srov. } \\
\text { Popisný } \\
\text { Předpis. }\end{array}$ \\
\hline $\begin{array}{l}\text { The Singapore } \\
\text { Smart Industry } \\
\text { Readiness } \\
\text { Index [23] }\end{array}$ & $\begin{array}{l}\text { EDB } \\
\text { Singa } \\
\text { pore } \\
\text { (2018) }\end{array}$ & $\begin{array}{l}\text { Prakt. } \\
\text { sdr. }\end{array}$ & 3 & B & $\begin{array}{l}6 \text { úrovní od 0 } \\
\text { po 5 } \\
\text { (Adaptivní) }\end{array}$ & Popisný \\
\hline
\end{tabular}




\begin{tabular}{|c|c|c|c|c|c|c|}
\hline $\begin{array}{l}\text { The Logistics } \\
4.0 \text { Maturity } \\
\text { Model [24] }\end{array}$ & $\begin{array}{l}\text { Olesk } \\
\text { ow- } \\
\text { Szlapk } \\
\text { a, } \\
\text { Stach } \\
\text { owiak } \\
(2019)\end{array}$ & Akad. & 3 & $A$ & $\begin{array}{l}5 \text { úrovní od } 1 \\
\text { (Ignorace) po } \\
5 \text { (Integrace) }\end{array}$ & Popisný \\
\hline $\begin{array}{l}\text { Roadmapping } \\
\text { towards } \\
\text { industrial } \\
\text { digitalization } \\
\text { based on an } \\
\text { Industry } 4.0 \\
\text { [25] }\end{array}$ & $\begin{array}{l}\text { Schu } \\
\text { mache } \\
r \text { et al. } \\
(2018)\end{array}$ & $\begin{array}{l}\text { Akad. } \\
\text { Prakt. } \\
\text { sdr. }\end{array}$ & 8 & $B$ & $\begin{array}{l}\text { Hodnocení do } \\
4 \text { úrovní. }\end{array}$ & $\begin{array}{l}\text { Popisný } \\
\text { Srov. }\end{array}$ \\
\hline $\begin{array}{l}\text { Contextualizin } \\
g \text { the outcome } \\
\text { of a maturity } \\
\text { assessment for } \\
\text { Industry } 4.0 \\
\text { [26] }\end{array}$ & $\begin{array}{l}\text { Colli } \\
\text { et al. } \\
\text { (2018) }\end{array}$ & Akad. & 5 & $B$ & $\begin{array}{l}6 \text { úrovní od } 1 \\
\text { (Bez } \\
\text { digitalizace) } \\
\text { po } 6 \\
\text { (Integrace) }\end{array}$ & $\begin{array}{l}\text { Popisný } \\
\text {. Srov. }\end{array}$ \\
\hline $\begin{array}{l}\text { Acatech } \\
\text { Industrie } 4.0 \\
\text { Maturity Index } \\
\text { [27] }\end{array}$ & $\begin{array}{l}\text { Zeller } \\
\text { et al. } \\
\text { (2018) }\end{array}$ & $\begin{array}{l}\text { Akad. } \\
\text { Prakt. } \\
\text { sdr. }\end{array}$ & 4 & $A$ & $\begin{array}{l}6 \text { úrovní od } 1 \\
\text { (Počátek IT) } \\
\text { po } 6 \\
\text { (Adaptabilní) }\end{array}$ & Popisný \\
\hline $\begin{array}{l}\text { Maturity and } \\
\text { Readiness } \\
\text { Model } \\
\text { for Industry } 4.0 \\
\text { Strategy [28] }\end{array}$ & $\begin{array}{l}\text { Akdil } \\
\text { et al. } \\
\text { (2018) }\end{array}$ & Akad. & 3 & $B$ & $\begin{array}{l}4 \text { úrovně od } 0 \\
\text { (Absence) po } \\
3 \text { (Připraven) }\end{array}$ & $\begin{array}{l}\text { Srov. } \\
\text { Popisný } \\
\text { Předpis. }\end{array}$ \\
\hline $\begin{array}{l}\text { A Smartness } \\
\text { Assessment } \\
\text { Framework for } \\
\text { Smart } \\
\text { Factories [29] }\end{array}$ & $\begin{array}{l}\text { Lee et } \\
\text { al. } \\
(2017)\end{array}$ & Akad. & 4 & $B$ & $\begin{array}{l}5 \text { úrovní od } 1 \\
\text { (Kontrolující) } \\
\text { po } 5 \\
\text { (Autonomní) }\end{array}$ & Popisný \\
\hline $\begin{array}{l}\text { Intelligent } \\
\text { Logistics For } \\
\text { Intelligent } \\
\text { Production } \\
\text { Systems [30] }\end{array}$ & $\begin{array}{l}\text { Krajco } \\
\text { vic et } \\
\text { al. } \\
(2018)\end{array}$ & Akad. & 7 & $A$ & $\begin{array}{l}\text { Hodnocení do } \\
5 \text { úrovní } \\
\text { (používá } 0 . \\
\text { úroveň). }\end{array}$ & $\begin{array}{l}\text { Popisný } \\
\text { Předpis. }\end{array}$ \\
\hline $\begin{array}{l}\text { Maturity Levels } \\
\text { For Logistics } \\
4.0 \text { Based On } \\
\text { NRW'S } \\
\text { Industry } 4.0 \\
\text { Maturity Model } \\
\text { [31] }\end{array}$ & $\begin{array}{l}\text { Gajše } \\
\text { k a } \\
\text { Sterna } \\
\text { d } \\
(2018)\end{array}$ & Akad. & 4 & $A$ & $\begin{array}{l}5 \text { úrovní od } 1 \\
\text { (Nepřipojený) } \\
\text { po } 5 \\
\text { (Kompletní) }\end{array}$ & Popisný \\
\hline
\end{tabular}




\begin{tabular}{|l|l|l|l|l|l|l|}
\hline Logistics 4.0 & Lewan & Akad. & 1 & A & $\begin{array}{l}\text { Hodnocení do } \\
\text { 6 úrovní, ke }\end{array}$ & $\begin{array}{l}\text { Popisný } \\
\text { Saturity in }\end{array}$ \\
dowsk & & & & kterým jsou & \\
Service & a a & & & & přidělené \\
Industry: & Kosac & & & & technologie & \\
Empirical & ka & & & & & \\
Research & $(2019)$ & & & & & \\
Results [32] & & & & & & \\
\hline
\end{tabular}

\subsection{Zhodnocení analyzovaných modelů}

$\checkmark$ rámci literární rešerše pro modely prípravenosti na Průmysl 4.0 bylo analyzováno celkem 35 modelů. $V$ tabulce jsou uvedeny pouze modely, které obsahují alespoň částečné hodnocení interní logistiky, jedná se tedy o modely skupiny $A$ a $B$, modely ve skupině $C$ neobsahují hodnocení interní logistiky. Některé modely jsou velmi komplexní, některé stručnější podoby. $U$ kvalitních 13 modelů bylo zaměřeno $z$ obecného hlediska logistiky postupně na oblasti interní logistiky. Interní logistika se jako samotná dimenze/oblast vyskytovala u malého množství modelů, proto byla také zkoumána obecně oblast logistiky, kde jsme následně hledali činnosti interní logistiky - například v oblasti skladování, manipulace, identifikace materiálu. Po přezkoumání a analýze modelů připravenosti je možné konstatovat, že žádný z modelů nehodnotí komplexně připravenost podniku $v$ rámci konceptu Průmyslu 4.0 v oblasti interní logistiky a nezaměřuje se specificky na danou oblasti. Nehodnotí celkově oblast interní logistiky, ani její dílčí činnosti či samotnou koncepci činností logistiky uvnitř podniku.

$U$ většiny modelů je obecně logistika obsažena $v$ rámci jedné dimenze/oblasti, případně se jí věnují dílčí dimenze či kritéria o otázky v rủzných dotaznících a hodnotících formulárích, nicméně je to pouze stručnější definována forma zaměření a také hodnocení. Oblast interní logistiky není jediným parametrem, který byl u modelů sledován a analyzován. Důležitým faktorem jsou úrovně hodnocení připravenosti. Analyzovaný je jejich počet, jejich charakteristika. Modely pracují s různými úrovněmi připravenosti $(0$ až 6$)$ a každá obsahuje minimální požadavky, které musí být splněny, aby byla úroveň dokončena. Úrovně jsou většinou od role outsidera, přes začátečníka, pokročilého, zkušeného, odborného až po největšího experta, některé modely zase využívají úrovně se stručnou charakteristikou od digitálního nováčka, integrovaného a interoperabilního, plně implementovaného až po zcela digitálně orientovaného subjektu.

To bylo napríklad důležitou součástí u modelů skupiny $C$, které nehodnotí interní logistiku, ale sloužily jako inspirace pro stanovení úrovní připravenosti pro nový navržený model. 


\section{Návrh modelu připravenosti pro hodnocení interní logistiky v kontextu Průmyslu 4.0}

Návrh modelu probíhal $v$ několika hlavních etapách. Každá etapa měla svoji specifikou náplň a byla stanovena posloupnost hlavních krokủ. Př́stup pro návrh nového modelu připravenosti zahrnoval systematický výzkum a hodnocení literatury a rozhovory sodborníky. Samozřejmostí je, že na počátku návrhu byla zkoumána literatura týkající se Průmyslu 4.0 a jeho hlavních definic. To byla základní vývojová fáze. Následně se autoři zaměřili na modely připravenosti, kterých bylo analyzováno celkem 35 . To byla hlavní vývojová fáze $\mathrm{k}$ návrhu a architektuře a struktuře nového modelu. Metodou abstrakce byla hledána oblast interní logistiky a u současných modelů byly shledány nedostatky pro tuto oblast, která má velký potenciál $v$ oblasti moderních technologií. Po tomto rozsáhlém systematickém výzkumu literatury o modelech připravenosti nebyl nalezen žádný podobný model připravenosti koncipovaný prrímo na interní logistiky s korespondencí na Průmysl 4.0. $\mathrm{Na}$ základě porovnání modelů bylo ale možné stanovit základní architekturu nového modelu. Modely byly porovnávány, analyzovány a jejich podobnost a principy sloužily jako inspirace pro nový model a stanovení relevantního rámce. $Z$ modelů byly odvozeny koncepty relevantní pro strukturu nového modelu, například hodnocené dimenze (obvykle 3 - 10 dimenzí), hodnocené úrovně (obvykle 4 - 6 úrovní), zpưsob hodnocení (vlastní interní hodnocení nebo hodnocení na základě externího auditora), způsob reprezentace (kvantifikace, grafická podoba hodnocení, atd.). Pomocí technik mapování konceptů byly extrahovány charakteristiky stávajících modelů prípravenosti a vyhodnoceny $z$ hlediska jejich použitelnosti pro náš model.

Další vhodné hledisko ovlivňující návrh a podobu modelu je zaměření autorů, kteří se specializuji na oblast průmyslového inženýrství na pracovišti Průmyslového inženýrství a managementu $v$ rámci akademického pole pưsobnosti. Vedle akademické oblasti je důležitá také průmyslová oblast, kde $\checkmark$ rámci spolupráce a workshopů probíhaly odborné rozhovory.

$\checkmark$ další fázi byl definován celkový design modelu, hodnocené dimenze a úrovně připravenosti a jejich charakteristiky. Definováno bylo celkem 5 dimenzí a 6 úrovní prípravenosti.

\subsection{Stanovení úrovní připravenosti}

Jakmile je dána hlavní architektura nového modelu, jsou stanoveny úrovně připravenosti. Tyto úrovně poté stanovují skutečnou digitální připravenosti podniku.

Stanoveno bylo 5 úrovní připravenosti +0 . úroveň, tedy celkově 6 úrovní připravenosti. $V$ této fázi se stručnou definicí se jedná o tyto úrovně:

- Úroveň 0 - Procesy nejsou explicitně definovány.

- Úroveň 1 - Certifikované procesní řízení. 
- Úroveň 2 - Digitalizovaný sběr dat ( $z$ procesů), zavádění automatizace.

- UÚroveň 3 - Část procesů je automatizována, napojení na externí zdroj dat.

- Úroveň 4 - Procesy jsou automatizované, s omezeným zásahem člověka.

- Úroveň 5 - Procesy jsou automatizované, člověkem kontrolované.

Stanovené úrovně mají vývoj a už podle stručné definice je představitelné, co daná úroveň znamená.

\subsection{Stanovení dimenzí a subdimenzí}

Interní logistika se zabývá materiálovým tokem a dále se věnuje i doprovodným tokem informací. Interní logistika poměrně široká oblast obsahující několik dalších dílčích oblastí. Proto do modelu připravenosti na koncept Průmyslu 4.0, který bude zaměřen na procesy interní logistiky, je nutné udělat rozdělení do hlavních dimenzí:

- Manipulace s materiálem

- Skladování

- Zásobování

- Balení

- Identifikace materiálu.

Těchto hlavních 5 dimenzí, které byly vybrány pro metodiku jako hlavní činnosti interní logistiky, je dále nutné rozpadnout na subdimenze, nebot' dimenze jsou velmi obecné a hodnotit ji jako celou oblast je neefektivní a nevypovídající, záměrem metodiky je detailní hodnocení.

a) dimenze manipulace:

Jedná se o proces, kdy dochází k manipulaci a přepravě materiálu. Materiál je přemístěn $z$ jednoho místa na druhé a zároveň je prováděna i informační změna lokace. Stanovené subdimenze:

- Manipulační technika

- Informační zajištění při manipulaci

- Manipulační jednotky

b) dimenze skladování

Jedná se o proces skladování materiálu, kde jsou hlavními činnostmi: naložit materiál a uložit na místo, zadat do informačního systému, kde je materiál uložen, způsob vyžádání materiálu ze skladu, fyzické vyndání, připravení k odvozu a opět informační zadání do systému. Stanovené subdimenze:

- Skladovací technologie 
- Informační zajištění při skladování

- Př́jem materiálu a expedice

c) dimenze zásobování

Zde se jedná o způsob zajištění materiálu ve výrobě, tedy mezi pracovišti ve výrobě nebo mezi výrobou a skladem materiálu. Dủležitá je používaná technika pro zavážení materiálu (náhodně, intervaly, Milcrun), jakým způsobem je materiál požadován (papírová objednávka, kanban, EDI, elektronický systém, systém prázdných obalů a volných pozic, apod.). Stanovené subdimenze:

- Technika pro zásobování pracovišt'

- Způsob závoz materiálu

- Informační zajištění odvolávek materiálu

d) dimenze balení

Balení je dnes velmi zásadním prvkem, který chrání výrobek před poškozením. Obaly jsou z různých materiálů, mají různé funkce (ochrana, prodyšnost, apod.), jiné obaly jsou mezi podniky, jiné mezi podnikem a spotřebitelem. Balit je možné ručně do kartonu s izolepou, je možné využívat různé nástroje a technologie, nebo je proces plně automatizovaný a robotizovaný. Stanovené subdimenze:

- Balící technologie, způsob balení

- Druhy obalů a obalový materiál

- Environment a obalové hospodářství

e) dimenze identifikace materiálu

Materiál pohybující se $\mathrm{v}$ prostoru podniku je nutno identifikovat $\mathrm{z}$ důvodů potřeby (rodokmenu) a $z$ důvodu lokace. Jedná se o proces umístění identifikátoru (to začíná přidáním papírového štítku a končí nalepeným čipem) a o proces snímání, načítání a zanášení do systému. Propojené výrobní a skladové systémy musí přesně vědět, kde, kdy a $v$ jakém množství je konkrétní součástka, aby tento moderní prístup $\mathrm{k}$ výrobě byl vůbec realizovatelný. Stanovené subdimenze:

- Způsob identifikace

- Informační zajištění a intenzita snímání

Byly vytvořeny vazby mezi jednotlivými úrovněmi a na jejich základě byl vytvořen průnik parametrů dimenze (subdimenze) a úrovně připravenosti. To bylo uděláno s ohledem nejen na současné používané technologie, ale i na předpokládané technologie na základě trendů a vývoje korespondujícím $\mathrm{s}$ Průmyslem 4.0 


\section{Diskuze}

Model prípravenosti pro hodnocení interní logistiky má celkem 5 dimenzí, respektive 14 dílčích subdimenzí. Dá se předpokládat, že těchto 14 subdimenzí dostatečným způsobem pokryje celou interní logistiku a bude tedy model možné nazývat komplexním. V současné době je výzkumným týmem zpracováno všech 14 subdimenzí a aby bylo možné model aplikovat do průmyslové oblasti, je nutné model dále rozvíjet a vyvijet systém hodnocení.

Výzkum pokračuje tvorbou systému hodnocení. Hodnocení bude provedeno na základě strukturovaného rozhovoru externím auditorem s pracovníky daného podniku. Každá otázka je koncipována tak, aby odpovídala odpovědi pro zařazení od 0 do levelu 5 . Respondenti by měli mít základní znalost 0 pojmech Průmyslu 4.0. Externí konzultace nebo skupinové sezení proto mohou zvýšit reprezentativnost dotazníku a presnost modelu. Odpovědi pak slouží jako datový vstup pro nástroj pro výpočet a reprezentaci úrovně připravenosti.

Výsledné hodnocení bude vzestupné od nejnižší položky, kterou je subdimenze. Po jejím vyhodnocení je možné získat hodnocení celé dimenze. A z jednotlivých dimenzí je následně provedeno hodnocení celé interní logistiky. Model má hlavně diagnostický charakter a stanovuje současnou úroveň připravenosti, nicméně je možné získat údaje o místech, která jsou tzv. úzkými místy. Cílem by mělo být pro tyto úzká místa zvyšovat úroveň vzestupně. Pokračování výzkumného týmu a další výsledky budou předmětem dalších článků.

\section{Závěr}

Řada firem, i na českém trhu, se pyšní tím, že již naplňují principy Průmyslu 4.0. Ve většině případů jde však pouze o dílčí inovace, které ve spojení $s$ novým pojmem dobře fungují coby marketingový nástroj. Průmysl 4.0 je spíše idea než konkrétní cíl a přechod k modernějším způsobům řízení logistických toků je organický proces. Firmy by měly myslet na to, aby nová technologická zařízení, která pořizují, byla připravena na integraci. $V$ dnešní terminologii hovoříme o kompatibilitě $v$ rámci internetu věcí. $V$ blízké budoucnosti bude důležité propojení všeho se vším a otevřenost. Spojování oblastí, jako je výroba, kvalita, logistika dodavatelů a rozpracovanost výroby, je správnou cestou. Oblast interní logistiky má tedy v rámci konceptu Průmyslu 4.0 velký potenciál a proto se výzkumný tým na průnik těchto dvou oblastí zaměřil a vyvijí nástroj, který bude hodnotit prípravenost podniku na tento koncept. Model by měl mít charakter popisný (deskriptivní), ale také předpisující (preskriptivní), jako mají některé $\mathrm{z}$ modelů, které byly analyzovány $\mathrm{a}$ porovnávány $v$ rámci literární rešerše. To bylo poměrně významnou fází, protože řada modelů byly inspirací a společné základy se mohly použít pro design nového modelu pripravenosti, který ale již hodnotí detailně pouze oblast interní logistiky. Cílem je vytvořit sofistikovaný detailní nástroj pro hodnocení interní logistiky pro průmyslové podniky bez rozdílu jejich velikosti. 


\section{Poděkování}

Tento článek byl vytvořen za podpory interního grantu Západočeské univerzity číslo projektu je SGS-2018-031 s názvem Optimalizace parametrů udržitelného výrobního systému.

\section{Použitá literatura}

[1] MUHURI, P. K., SHUKLA, A. K., ABRAHAM, A. Industry 4.0: A bibliometric analysis and detailed overview. Engineering applications of artificial intelligence, 2019, 78, 218-235.

[2] SARVARI, P. A., USTUNDAG, A., CEVIKCAN, E., KAYA, I., CEBI, S. Technology roadmap for Industry 4.0. In Industry 4.0: Managing the digital transformation. 2019, pp. 95-103. Springer, Cham

[3] KAGERMANN, H., HELBIG, J., HELLINGER, A., and WAHLSTER, W. Recommendations for implementing the strategic initiative INDUSTRIE 4.0: Securing the future of German manufacturing industry. 2013. Forschungsunion.

[4] BOTLÍKOVÁ, M., BOTLÍK, J. Local Extremes of Selected Industry 4.0 Indicators in the European Space - Structure for Autonomous Systems, Journal of Risk and Financial Management, 2020, vol. 13, pp. 1-39.

[5] VAIDYA, S., AMBAD, P., BHOSLE, S. Industry 4.0 - a glimpse. Procedia Manufacturing, 2018, 20, pp. 233-238.

[6] GUNAL, M. M. (Ed.). Simulation for Industry 4.0: Past, Present, and Future. 2019, Springer.

[7] MAŘíK, V. Průmysl 4.0: výzva pro Českou republiku. Praha: Management Press, 2016. ISBN 9788072614400.

[8] Národní iniciativa Průmysl 4.0. Ministerstvo průmyslu a obchodu. [online], [cit. 28.1.2020]. Dostupné z:

https://www.mpo.cz/assets/dokumenty/53723/64358/658713/priloha001.pdf

[9] WANG, K. Logistics 4.0 Solution - New Challenges and Opportunities, 6th International Workshop of Advanced Manufacturing and Automation, Atlantis Press, 2016, pp. 68-74.

[10] HORENBERG, D. Applications within Logistics 4.0, Twente, 2017. Bachelor Thesis. University of Twente, The Faculty of Behavioural, Management and Social sciences

[11] GALINDO L, The challenges of logistics 4.0 for the supply chain management and the information technology, 2016. Master's thesis. Norwegian University of Science and Technology

[12] GLISTAU E., COELLO MACHADO N. I. Industry 4.0, logistics 4.0 and materials-Chances and solutions. In Materials Science Forum, 2018, Vol. 919, pp. 307-314.

[13] ZOU O., ZHONG R. Y., Automatic Logistics in a Smart Factory using RFIDenabled AGVs. IEEE/ASME International Conference on Advanced Intelligent Mechatronics (AIM) 2018, pp. 822-826. 
[14] CMMI® for Development, Version 1.3: CMMI-DEV, V1.3 [online]. The Software Engineering Institute, Carnegie Mellon University. 2010 [cit. 1.2.2020]. CMU/SEI-2010-TR-033. Dostupné z:

https://resources.sei.cmu.edu/asset files/TechnicalReport/2010 0050011 $\underline{\text { 5287.pdf }}$

[15] MUTAFELIJA, B., STROMBERG. H. Process improvement with CMMI v1.2 and ISO standards. Boca Raton: CRC Press, c2009. ISBN 978-1-42005283-1.

[16] PAULK, M. C., CURTIS, B., CHRISSIS, M.B., WEBER, Ch. V., Capability Maturity ModelSM for Software, Version 1.1 [online]. Version 1.1. Pittsburgh: The Software Engineering Institute, Carnegie Mellon University. 82 s. [cit. 15.2.2020]. CMU/SEI-93-TR-024. Dostupné z: https://resources.sei.cmu.edu/asset files/TechnicalReport/1993005001 1 6211.pdf

[17] BRUCKNER, T., Tvorba informačních systémů: principy, metodiky, architektury. Praha: Grada, 2012. Management v informační společnosti. ISBN 978-80-247-4153-6.

[18] VIHAROS, Z. J., S. SOÓS, G. NICK, T, VÁRGEDO a R. BEREGI. Noncomparative, Industry 4.0 Readiness Evaluation for Manufacturing Enterprises. Technical Diagnostics in Cyber-Physical Era [online]. Budapest, 2017 [cit. 1.3.2020]. Dostupné z:

https://pdfs.semanticscholar.org/7208/6b065f0f5bd54b21a9683694b1a8dd8 a5246.pdf

[19] BASL, J. Companies on the way to industry 4.0 and their readiness. Journal of Systems Integration, 2018, 9, pp. 3-6.

[20] LICHTBLAU, K., V. STICH, R. BERTENRATH,. Industrie 4.0 Readiness. [online]. Aachen, Cologne. 2015 [cit. 3.3.2020]. Dostupné z: https://industrie40.vdma.org/documents/4214230/26342484/Industrie $40 \mathrm{R}$ eadiness Study 1529498007918.pdf/0b5fd521-9ee2-2de0-f37793bdd01ed1c8

[21] CAROLIS, A. D. A toolkit to guide manufacturing companies towards digitalization [online]. Milán, 2018 [cit. 2020-01-15]. Dostupné z: https://www.alpine-space.eu/projects/smart-space/results/wpt3/smartspace sv7 dreamy assessment and testindustria4.0 politecnico.pdf

[22] AGCA, O., GIBSON, J., GODSELL, J., IGNATIUS, J., DAVIES, C. W., XU, O. An Industry 4 readiness assessment tool. 2017, University of Warwick, Warwick.

[23] The Singapore Smart Industry Readiness Index: Catalysing the transformation of manufacturing [online]. Singapore: Singapore Economic Development Board, 2018 [cit. 25.3.2020]. Dostupné z: https://www.gov.sg/ /sgpcmedia/media releases/edb/press release/P_ 201711131/attachment/The\%20Singapore\%20Smart\%20Industry\%20Readiness $\% 201$ ndex\%20-\%20Whitepaper final.pdf

[24] OLEŚKÓW-SZŁAPKA, J., STACHOWIAK, A, The framework of logistics 4.0 maturity model. International Conference on Intelligent Systems in 
Production Engineering and Maintenance 2018, pp. 771-781. Springer, Cham.

[25] SCHUMACHER, A., EROL, S. SIHN, W. A Maturity Model for Assessing Industry 4.0 Readiness and Maturity of Manufacturing Enterprises. Procedia CIRP, 2016, 52, pp.161-166.

[26] COLLI, M., MADSEN, O., BERGER, U., MØLLER, Ch., WAEHRENS, B., BOCKHOLT, M. Contextualizing the outcome of a maturity assessment for Industry 4.0. IFAC-PapersOnLine. 2018. 51. pp. 1347-1352.

[27] ZELLER, V., HOCKEN, C., STICH, V. Acatech Industrie 4.0 Maturity Index A Multidimensional Maturity Model. Advances in Production Management Systems. Smart Manufacturing for Industry 2018, 4.0, pp. 105-113.

[28] AKDIL, K., USTUNDAG, A., CEVIKCAN,E. Maturity and Readiness Model for Industry 4.0 Strategy. Springer Series in Advanced Manufacturing, 2018, pp. 61-94.

[29] LEE, J., JUN, S., CHANG, T. W., PARK, J. A Smartness Assessment Framework for Smart Factories Using Analytic Network Process. Sustainability, 2017, 9(5), p. 794.

[30] KRAJCOVIC, M., GRZNAR, P., FUSKO, M., SKOKAN, R. Intelligent Logistics for Intelligent Production Systems. Communications - Scientific Letters of the University of Zilina, 2018, 20(4), pp. 16-23.

[31] STERNAD, M., LERHER, T., GAJSEK, B. Maturity Levels For Logistics 4.0 Based on Nrw's Industry 4.0 Maturity Model. Business Logistics in Modern Management, 2018, 18, pp. 695-708.

[32] WERNER-LEWANDOWSKA, K., KOSACKA-OLEJNIK, M. Logistics maturity of the service industry - research results. Prace Naukowe Uniwersytetu Ekonomicznego we Wrocławiu. 2019. 63. pp. 233-248. 